\title{
A Review of Literature of Global Value Chains
}

\author{
Sourish Dutta \\ $\mathrm{PhD}$ Student \\ Centre for Development Studies \\ Trivandrum, Kerala
}

\begin{abstract}
The phenomenon of global value chains (GVCs) indicates a division of labour type production structure in which tasks and business functions are distributed among several companies, globally, or regionally (Grossman and Rossi-Hansberg 2008). The critical features of GVCs are therefore the international dimension of the production process and the "contractualisation" of buyer and seller relationships, often across international borders (Antras 2016). As a result, these international production networks are highly complex regarding geography, technology, and the different types of firms involved (from large retailers and highly large-scale mechanised manufacturers to small home-based production). Sometimes it may be impossible even to identify all the countries that are involved or the extent of their involvement (Gereffi and FernandezStark 2016). However, the recent development of OECD-WTO's Trade-in Value Added (TiVA) data represents a fundamental step forward in understanding GVC trade. Grossman \& RossiHansberg $(2008,2012)$ rightly point out that the different tasks, rather than sectors, define the specialisation of countries in the value chains.
\end{abstract}

\section{Broad Perspective}

Internationally fragmented production is not new. For decades, low- and middle-income countries (LMICs) have imported parts from countries with more advanced technology, although generally only for the assembly of locally sold goods. Because the goods produced were not part of a global network, flows of know-how were less intense. The new characteristic of GVCs from a development perspective is that factories in LMICs have become full-fledged participants in international production networks. They are no longer just importing parts for assembly for local sales. They are 
exporting goods, parts, components, and services customized to the needs of the intended buyers and used in some of the most sophisticated products on the planet (Taglioni \& Winkler 2016).

Given the need for customization and integration of production facilities internationally, large multi national corporations (MNCs) seek to improve local innovation, knowledge-based capital, and competencies. The Samsung Group—which employs 369,000 people in 510 offices worldwide—worries about shortages of technical and engineering skills in Africa and how those shortages affect its efforts to embed its African workforce in Samsung's global production networks. In 2011, to address such shortages, Samsung launched Samsung Electronics Engineering Academies in Kenya, Nigeria, and South Africa. Outstanding performers are sent to annual Learner ship Programs in Seoul as part of Samsung's program for young leaders. The initiative serves the company's broader goal to develop 10,000 electronics engineers across the continent by 2015 (ACET 2014). Other corporations are investing in building the skill base in LMICs, too (Dunbar et al. 2013). Lucent Technologies supports education and learning programs in 16 countries throughout Africa, Asia, Europe, and Latin America; Nike and the United Kingdom's Department for International Development run a program to support access to economic assets for adolescent girls; Microsoft provides support to incorporate information technology (IT) into the daily lives of young people in the Philippines, Poland, the Russian Federation, and South Africa; Cisco provides funds, expertise, and equipment to create national networks of IT training centers in India, Mexico, South Africa, and the West Bank and Gaza, in addition to the work of the Cisco Networking Academy, which has 10,000 academies in 165 countries; finally, Nokia enhances life skills and leadership skills of young people in several countries, including Brazil, China, and Mexico (Taglioni \& Winkler 2016).

The new GVC-enabled flow of know-how from high-income countries to LMICs is a key factor in determining the role of GVCs in industrial development. LMICs can now industrialize by joining GVCs without the need to build their own value chain from scratch, as Japan and the Republic of Korea had to do in the twentieth century (Baldwin et al. 2012). That enables LMICs to focus on specific tasks in the value chain rather than producing the entire product, thereby lowering the threshold and costs for industrial development. LMICs can benefit from foreign-originated intellectual property; trademarks; operational, managerial, and business practices; marketing expertise; and organizational models. Countries have to understand the opportunities that GVCs offer and adopt the appropriate policies to mitigate the risks associated with them have the opportunity - through GVCs - to boost employment and productivity in all their agriculture, manufacturing, and services production. Job creation and labor productivity growth are sometimes viewed as competing goals, as higher labor productivity enables firms to produce a larger amount of value added without necessar- 
ily increasing the number of workers at the same rate (static productivity effects). Research shows that GVC integration leads to higher net jobs but lower job intensity (Calì et al. 2016, 2015) and has strong potential for productivity gains via several transmission channels (dynamic productivity effects), as discussed later, which go in hand with increased labor demand caused by more vertical specialization and higher output in GVCs.

\section{Firm Perspective}

The international location of new production facilities is ultimately in the hands of GVC lead firms. Conceptually, the new possibilities created by globalization and the information and communications technology revolution create two distinct sets of necessities for firms, which countries must address: (1) connecting factories and (2) protecting assets. Because cross-border factories must work as a unit, lead firms in GVCs care about efficiently connecting local factories with the relevant international production network and protecting proprietary assets. The predictability, reliability, and time sensitivity of trade flows are important factors behind firms' decision about a location, according to major trade and competitiveness indexes and case studies (WEF 2013). In many cases, countries cannot participate in certain parts of GVCs because of requirements for timely production and delivery. In effect, time is money in GVCs. A day of delay in exporting has a tariff equivalent of 1 percent or more for time-sensitive products (Hummels et al. 2007). Slow, unpredictable land transport keeps most of Sub-Saharan Africa out of the electronics value chain (Christ \& Ferrantino 2011). Lead firms and intermediate producers in GVCs need reliable, predictable, and timely access to inputs and final products to satisfy demand on time. Hence, good infrastructure and efficient borders are critical, as they relate to the predictability, reliability, and time sensitivity of trade flows.

Strong, well-enforced property rights are the other element essential to attracting and keeping foreign investors (Feenstra et al. 2013). Firms export valuable, firmspecific technology and know-how, only part of which can be protected through patents, trademarks, and other forms of intellectual property regulations (IPRs). The know-how embodied in business and organizational models, operational and managerial practices, production processes, and export processes cannot be patented or trademarked; and even when intellectual property can be patented or trademarked, IPR treaties and domestic regulations aimed at promoting fair competition only imperfectly protect such know-how. Because GVCs necessarily involve contracting relationships between agents located in countries with heterogeneous legal systems and contracting institutions, "contracts are often neither explicit nor implicit; they simply remain incomplete" (Rodrik 2000). The way in which different national 
systems deal with contractual frictions and incomplete contracts and the way host countries enforce contracts between private parties are additional elements driving firms' choice of location, and those elements also factor into firms' boundaries in global sourcing (Antràs \& Chor 2013, Antràs \& Yeaple 2015). The connectivity of factories and the nature of contracting across countries are therefore key determinants - along with capital intensity — of a firm's decision to make or buy and whether to do so domestically or internationally.

Control of the subsidiary takes place in a variety of ways. The most strategic assets are tied to the lead firm through forms of direct capital control over the supplier (such as majority equity stakes). Assets of lower importance (such as older technologies) are instead just handed over through licensing agreements or other non-equity investments. Technical cooperation and arm's-length trade signal looser forms of collaboration. With the dramatic growth of outsourcing practices, competition between companies has shifted from horizontal (with firms competing in the same sector for the same customer base) to vertical (with firms in the same value chain competing to perform specific and specialized tasks). Lead firms compete with first-tier and lower-tier suppliers (Milberg 2004, Cattaneo et al. 2013, Cattaneo \& Miroudot 2013).

\section{Policy Perspective}

In the same way that import substitution industrialization gave way to export-oriented industrialization, the latter is now being replaced by efforts to identify an entry point into vertically specialized industries and upgrade within GVCs. Attracting offshore factories and ensuring domestic firm participation in international GVCs has become a major priority for many policy makers in LMICs. From a policy perspective, however, the critical issue is how GVCs integrate into the economy as a whole. Attracting and keeping offshore factories is not enough. Opening borders and attracting investment are important and help jump-start entry in GVCs. But to retain GVCs, maximize their benefit to the domestic economy, and ensure their sustainability, countries must integrate the domestic productive sector. The policy challenge extends, therefore, to creating and strengthening links with domestic firms and ensuring that the host country benefits from technology transfers, knowledge spillovers, and increased value addition in the country. If GVCs remain de-linked from the local context, lead firms drive many decisions, and governments may have limited influence and ability to leverage such decisions for domestic economic development. It is equally important to ensure that GVC participation benefits domestic society through more and better-paid jobs, better living conditions, and social cohesion. The right strategies can help LMICs increase and strengthen 
their participation in GVCs and foster development. Therefore, one of my aims (in this proposal) will be to discuss those right strategies with their enforcement and implications (quantitative as well as qualitative).

Nevertheless, a point to remember is that to create an effective and sustainable strategy of GVC participation, governments must focus on identifying key binding constraints and designing the necessary policy and regulatory interventions—as well as infrastructure and capacity building-with a "whole of value chain approach". Such an approach is needed to achieve development objectives through GVC participation and address specific challenges in entering GVCs, expanding and strengthening participation, and ensuring sustainability and inclusive growth. Trade and investment policies need to be connected with a wide-ranging domestic reform agenda aimed at helping countries enhance firms' productivity by building internal capacities and providing access to capital and connectivity, and ensuring a responsive and effective governance structure for identifying opportunities and addressing challenges from GVC participation.

According to Taglioni \& Winkler (2016), GVCs require targeted policies and analysis across a wide range of areas, which may not always be easy for a country's policy makers to formulate and connect to each other and to GVCs. Governments may not necessarily be aware of the effects of domestic policies on integration and upgrading in GVCs. The odds of success in GVCs are affected by policy and its implementation in areas as different as trade (tariff and nontariff barriers), domestic services regulations, investment regulations and incentives, compliance with process and product standards, innovation, industry, entrepreneurship, labor markets, education, and infrastructure and connectivity. Countries may not appreciate fully the importance of the synergies between the core areas of trade and investment regulation and well-tailored complementary measures. Countries also may not be able to identify the appropriate investment in education and vocational training, infrastructure, and connectivity; the best setting for labor market policies; which international standards to adopt; how to design and develop adequate supplier programs; effective cluster development programs and competitive spaces (special economic zones, growth poles, growth corridors, and so forth); or services regulations conducive to business efficiency. Finally, countries may not be able to identify and implement sustainable and effective financing and incentive schemes.

Even when governments are aware of these issues, putting in place regulations that do not unnecessarily restrict effectiveness in GVC participation may be difficult. In most countries, many agencies have a role in setting and enforcing regulation that may affect value chains and the efficiency of their supply chain. Those agencies also often legislate and implement regulation in an uncoordinated manner because regulators set policies with domestic regulatory objectives in mind. As a 
consequence, international coordination is not necessarily able to foster GVCs' production and trade along the corresponding supply chain. International coordination conflicts with domestic regulatory objectives may explain why existing trade agreements, investment agreements, and similar forms of international cooperation are rarely designed to foster GVC participation (Hoekman 2014).

Given this background, OECD, WTO, World Bank, and different international as well as regional institutions are constantly suggesting that the policy maker's priority should be to identify and lift binding constraints, unlock productivity growth, and improve the overall competitiveness of the country. Many governments are willing to invest significant time and effort to adopt policy that influences the cost of production and trade within a GVC. The appropriate analysis and policy strategies can help trigger a virtuous cycle of "reform—GVC entry and upgrading—development", whereby the private sector is encouraged to keep investing retained earnings in the continued improvement of existing activities, new activities, and comparative advantage tasks in countries' agriculture, manufacturing, and services sectors, thereby generating a process of inclusive growth for the host country.

\section{Innovation Perspective}

Pietrobelli \& Rabellotti (2011) shows that Innovation, as a chain of processes, interact with GVC in multiple ways, and influence whether and how developing country firms learn and innovate through entering and interacting in these value chains. In general, LDC firms learn and innovate based on their participation in the GVC because they have to satisfy the product quality, delivery time, process efficiency, environmental, labor and social standards requirements of these chains. The learning mechanisms within GVC vary according to the form of governance that is adopted: they can be the result of pressure to match international standards or may be facilitated by direct involvement of the value chain leaders if the competence of suppliers is low and the risk noncompliance is high. When the actors in the value chain have complementary competences, learning is mutual and based on intense face-to-face interactions. In fact, it is from the 1980s on, with the debates surrounding the interpretation of the innovation process, that the perspective of innovation as a systemic and interactive process appears in the academic literature and in OECD policy documents, highlighting the importance of firms' both formal and informal networks, and giving rise to the concept of the innovation system (Szapiro 2016).

According to Lundvall et al. (2015), the notion of Innovation Systems, initiated by Economists bringing in the social dimension, is predominantly national level with advice on the design of na- 
tional institutions and state policies for interactive learning between equal partners. Whereas the GVC approach, initiated by Sociologists bringing in economic perspectives, is developed to overcome limitations of nation state perspectives, where "governance" as the power dimension between the lead firm and the other firms in the value chain. Innovation System and Global value chain approach both see the promotion of development in less developed economies as the objective. Although these two approaches have common objective, but they are different mechanisms. Innovation system approach is about building absorptive capacity in less developed economies. Global value chain is about upgrading firms through linking up with foreign lead firms. Moreover, in terms of policy implications, the GVCs framework suggests that reducing trade barriers and policies aimed at attracting subsidiaries of multinational firms become a better alternative to industrial policies focused on substituting imports and increasing local content (Gereffi \& Sturgeon 2013). The literature on innovation systems, on the other hand, provides important elements for the understanding of the capability building process within firms, industries and sectors in developing countries (Szapiro 2016).

Actually, each approach has some obvious limitations. We know (from policy perspective) that to design intelligent institutions and policies at the national level requires an understanding of of the openness of the innovation system, which limits the scope of national system of innovation. Managing the openness including the dependence of foreign multinational firms is a major challenge for national governments. On the other hand, to understand how and to what degree a specific firm's or cluster's integration in a global value chain contributes to economic development requires an understanding of the national innovation system as context. However, there is a couple of earlier attempts to overcome these limitations. Pietrobelli \& Rabellotti (2011) started from Global Value Chain analysis and argue for including local, regional and national institutions' roles in upgrading opportunities. Ernst \& Kim (2002) started from Innovation System perspective and point to the need to take into account the role of global networks in relation innovation strategies. Malerba \& Nelson (2010) emphasised on catching-up and sectoral systems also combined the two perspectives. Indeed, the relationship between the GVC and IS is intrinsically dynamic, with frequent two-way directions of causality and continuous feedback. Governance patterns in GVC are dynamic and subject to continuous adjustments and changes. The characteristics of the innovation system affect this evolution. Therefore I should explore the co-evolving link between suppliers and the lead firms, and with them, of the related IS. 


\section{References}

ACET (2014), African transformation report: Growth with depth, Technical report, African Center for Economic Transformation, Accra, Ghana: ACET.

Antràs, P. \& Chor, D. (2013), 'Organizing the Global Value Chain', Econometrica 81(6), 21272204.

Antràs, P. \& Yeaple, S. R. (2015), 'Multinational Firms and the Structure of International Trade', Handbook of International Economics 4, 55-130.

Baldwin, R., Venables, A. J. \& Bridgman, B. (2012), 'Global supply chains: Why they emerged, why they matter, and where they are going', Journal of International Economics 90(1), 245-254.

Calì, M., Francois, J., Hollweg, C. H., Manchin, M., Oberdabernig, D. A., Rojas-Romagosa, H., Rubinova, S. \& Tomberger, P. (2016), 'The labor content of exports database', World Bank Policy Research Working Paper 7615 .

Calì, M., Hollweg, C. et al. (2015), The labor content of exports in south africa and botswana, Technical report, The World Bank.

Cattaneo, O., Gereffi, G., Miroudot, S. \& Taglioni, D. (2013), 'Joining, upgrading and being competitive in global value chains: a strategic framework', World Bank Policy Research Working Paper 6406 pp. 1-50.

Cattaneo, O. \& Miroudot, S. (2013), 'From global value chains to global development chains: An analysis of recent changes in trade patterns and development paradigms', 21st Century Trade Policy: Back to the Past .

Christ, N. \& Ferrantino, M. J. (2011), 'Land Transport for Export: The Effects of Cost, Time, and Uncertainty in Sub-Saharan Africa', World Development 39(10), 1749-1759.

Dunbar, M. et al. (2013), 'Engaging the private sector in skills development', Health \& Education Advice and Resource Team. Oxford Policy Management, Oxford, England .

Ernst, D. \& Kim, L. (2002), 'Global production networks, knowledge diffusion, and local capability formation', Research policy 31(8), 1417-1429.

Feenstra, R. C., Hong, C., Ma, H. \& Spencer, B. J. (2013), 'Contractual versus non-contractual trade: The role of institutions in China', Journal of Economic Behavior and Organization 94, 281-294. 
Gereffi, G. \& Sturgeon, T. (2013), 'Global value chain-oriented industrial policy: the role of emerging economies', Global value chains in a changing world p. 329.

Hoekman, B. (2014), 'Supply chains, mega-regionals and multilateralism: a road map for the wto', Robert Schuman Centre for Advanced Studies Research Paper No. RSCAS 27.

Hummels, D., Minor, P., Reisman, M. \& Endean, E. (2007), ‘Calculating tariff equivalents for time in trade', USAID Report, March .

Lundvall, B., Jurowetzki, R. \& Lema, R. (2015), 'Combining the global value chain and the innovation system perspectives', Aalb. Univ. Dep. Bus. Manag .

Malerba, F. \& Nelson, R. (2010), Catching up in different sectoral systems: evidence from six industries, in 'Globelics Conference, Kuala Lumpur, Malaysia', p. 2010.

Milberg, W. (2004), 'The changing structure of trade linked to global production systems: What are the policy implications?', International Labour Review 143 (1-2),(1), 45-90.

Pietrobelli, C. \& Rabellotti, R. (2011), 'Global value chains meet innovation systems: are there learning opportunities for developing countries?', World Development 39(7), 1261-1269.

Rodrik, D. (2000), 'How Far Will International Economic Integration Go?', Journal of Economic Perspectives 14(1), 177-186.

Szapiro, M. (2016), Global Value Chains and National Systems of Innovation: policy implications for developing countries, $\mathrm{PhD}$ thesis, Universidade Federal do Rio de Janeiro.

Taglioni, D. \& Winkler, D. (2016), Making Global Value Chains Work for Development, Vol. Trade and Development series, Washington, DC: World Bank.

WEF (2013), Enabling trade: Valuing growth opportunities, in 'World Economic Forum'. 